\title{
Workplace Barriers and Leadership Conflicts Experienced by the Women in Higher Education in Saudi Arabia
}

\author{
Afaf Awad Alsubhi \\ Faculty of Education, University of Malaya \\ 50603, Kuala Lumpur, Malaysia \\ E-mail: afaf.uk2013@gmail.com \\ Kazi Enamul Hoque (Corresponding author) \\ Faculty of Education, University of Malaya \\ 50603, Kuala Lumpur, Malaysia \\ E-mail: tffr2011@yahoo.com \\ Ahmad Zabidi Abdul Razak \\ Faculty of Education, University of Malaya \\ 50603, Kuala Lumpur, Malaysia \\ E-mail: zabidi@um.edu.my
}

Received: February 13, 2018 Accepted: March 27, 2018 Published: April 16, 2018

doi:10.5296/ijld.v8i2.13007ＵRL: https://doi.org/10.5296/ijld.v8i2.13007

\begin{abstract}
Based on the published scholarly works, this paper attempts to explore and accumulate the challenges and barriers that Saudi women leaders in higher education are experiencing in their professional lives. For this purpose, literature review method has been adopted. Relevant scholarly articles published in 2004 to 2017 have been rigorously studied and cited. Findings of this paper suggest that women leaders in higher education generally experience assorted challenges, such as 1) socio-cultural, 2) organizational, 3) economical and 4) personal. They
\end{abstract}


also encounter eight workplace berries, such as 1) gender-based stereotypes, 2) work-life conflict, 3) self-imposed constraints, 4) social network limitations, 5) biased organizational policies, 6) non-gender-based discrimination, 7) inadequate qualification and 8) minimal existing representation. The findings also suggest that these challenges and barriers decrease the job-performances of the women leaders while igniting conflicts with their male counterparts. This paper can be helpful to the policy maker in formulating effective solutions for women leadership conflicts in Saudi Arabia. Besides, it may create new scopes for the researchers and academicians to conduct empirical studies in this very realm.

Keywords: Women leadership, leadership conflict, Saudi Arabia

\section{Background}

The Kingdom of Saudi Arabia (KSA) has adopted Islamic religious principles as well as traditional tribal rules in its governing system. That is why, Saudi society which is excessively patriarchal and men dominated generally discourages women to participate in formal job in the public sphere (Vidyasagar \& Rea, 2004). But, over the last decades this nation observed remarkable changes in its socio-economic policy. Government has taken substantial initiatives for building a knowledge-based economy. In this regard, women's access to education as well as job market were given high priority. As a result, nowadays, increasing number of graduated women are participating in the Saudi labour market (Faisal, 2012; Ministry of Higher Education, 2013; Nisreen \& Nadia, 2011). In last 10 years, women's participation in the management has outstandingly raised in both public and private sectors (Al-Ahmadi, 2011; Alotaibi, Cutting, \& Morgan, 2017; Danish \& Smith, 2012; Oplatka \& Herts-Lazarovits, 2006). Saudi women are entering the workforces, participating as leaders in university education. These phenomena are examples of women transitioning to decision making roles (Al-bakr, Bruce, Davidson, Schlaffer, \& Kropiunigg, 2017). Such engagement of women in the economic exercise is proven has positive impacts on the national economy as well as household wellbeing of Saudi (Nisreen \& Nadia, 2011). But, they are experiencing numerous obstacles in both social and institutional contexts (Danish \& Smith, 2012; Rajeh, Nicolau, Pluye, Qutob, \& Esfandiari, 2017). They meet discrimination in corporate culture in case of recruitment, retention and promotion. Besides, also experience the behavioral and cultural issues that are rooted into stereotyping, tokenism, power, preferred leadership style and the psychodynamics of male and female relations (Oakley, 2000). Long prevailed patriarchal social structure, old fashioned organizational decorum and conservative perception of individuals are creating the adverse realities for Saudi women. Therefore, women's leadership is getting severely barred and turning out to conflicts with their male counterparts (Al-Ahmadi, 2011; Danish \& Smith, 2012; Abdallah M. Elamin \& Omair, 2010; Thompson, 2015). This contravention is slowing down the personal progress of women and the expected organizational outcomes as well. Nowadays, Saudi women are seemingly partaking in education leadership and facing contra-realities, disputes and conflicts (Al-Ahmadi, 2011).Alike other sectors, in higher education they are experiencing tremendous challenges that are being concluded in to conflicts with their male counterpart (Al-Ahmadi, 2011; Al - Lamky, 2007; M. Almunajjed, 1997; Danish \& Smith, 2012; Nisreen \& Nadia, 2011; Thompson, 2015). Elimination of women leadership-conflict seems becoming a 
crucial need for their development as well as institutional wellbeing. In this regard, it is imperative to explore the actual causative factors behind the conflicts. This realisation has made the basis of this paper.

\subsection{Objective}

By reviewing the published scholarly articles, this paper aims at exploring and accumulating the causative factors behind women leadership conflict in higher education in Saudi Arabia.

\section{Methodology}

This paper adopted literature review method to explore and accumulate the causative factors behind leadership conflicts that Saudi women are experiencing in higher education. Relevant scholarly articles were synthesised and rigorously cited upon cautiously avoiding publication bias (Salkind, 2010). Articles that were published from 2004 to current year (2017) were randomly selected form 'google scholar'. It is noteworthy, the year 2004 is considered as a turning point for women rights (Note 1) in Saudi (Europian-Parliament, 2004; Human-Rights-Watch, 2004).

\section{Literature Review}

\subsection{Government Initiatives for Women Development in Saudi}

The government of Saudi Arabia has taken initiatives for enhancing women education. In this regard, the allocation for post-secondary education has been significantly increased while inspiring the privatization of higher education (Nisreen \& Nadia, 2011). The visionary king Abdul Aziz realized the essence of education as a way forward to ensure sustainable development. His successors have taken necessary steps to turn that dream into reality. The ministry of education chalked out a 10 years' strategic plan (2004-2014) in order to materialize King Abdullah's vision and about SR105 billion in 2008 and SR 204 billion in 2012 was allocated for building strong educational infrastructure (Mohammed, 2013) which was $5.6 \%$ of total GDP (In 2012) (UNDP, 2013). In 2013, the budget for education was SR 77.2 billion which was $9 \%$ of the total budget of the country ( Ministry of Higher Education, 2013) (Note 2). This enhanced budget reflects Kingdom's vision and seriousness to build a knowledge based economy (Neva, Hala, \& Gregory, 2014). However, this kingdom has built 34 universities and 543 affiliated colleges that comprises 2,393 departments. King Abdul-Aziz University in Jeddah has the highest number of students in the country (Mohammed, 2013). The education system in Saudi was run under three entities, such as the Ministry of Education, Ministry of Higher Education and the Technical and Vocational Training Corporation (Ministry of Education, 2004). However, in 2015 The Ministry of Education and Higher Education were merged into one entity, the Ministry of Education (Ministry of Education, 2015). Male and female students are separated based on the gender segregation policy (Al-Jaradat, 2014; Havril, 2015). The literacy rate of the male youth (15-24) was $99 \%$ and female youth was (15-25) 97\% by 2012 (UNICEF, 2013). Keen attention has been to improve the quality of women education. For this purpose, government 
has extended financial assistance to the female students across the county (Nisreen \& Nadia, 2011). The first girls' college was established in 1970 in Riyadh, while 10 other colleges were established in all over the country by the $80 \mathrm{~s}$ in order to enhance women education. Arts, education, general science, mathematics, religion, Arabic, geography, history, English, psychology and home economics are included in the curriculums. So far, there are 38 educational institutes for women including 8 universities that have been operating under the Ministry of Education. Women are representing 58\% of the total pupils (Nisreen \& Nadia, 2011). The literacy rate of women roused from $2 \%$ in 1970 to $97 \%$ (Female youth age between 15-25 years) by 2012 (UNICEF, 2013) . In this case, University Princes Nora bint Abdul Rahman, which was established in 2009 is playing the most important roles (Mohammed, 2013). Overall, half of the students, who have been graduated in recent years are women. These statistics show that there is an outstanding growth of women participation in education. Thus they are facing the light of empowerment (Faisal, 2012). As a result, women are being qualified to participate in the management. But, due to long prevailed patriarchal social norm, man dominated organizational culture and conservative religious belief women are experiencing typical barriers in performing duties and getting into conflicts with their male counterparts.

\subsection{Barriers Generally Faced by the Women}

Women are generally facing multiple barriers in their professional lives. For instance, gendered cultural, low opportunity for participating in education, discrimination, majority male teachers in the education system, low confidence and self-esteem, burdensome tasks, lack of empowerment and communication (Abu-Khader, 2012; Al-Jaradat, 2014; Al-Kubaisi, 2004; Al-Minqash, 2007). The barriers include gender discrimination in the workplace, gender stereotypes, lack of mobility, limited opportunity for growth and career development, excessive workload, lack of family-work balance, gender based challenges related with pregnancy (Al-Asfour et al., 2017). Even the governing board of the women' educational institutions are predominately in the hands male religious authority (Omair, 2008). Women also encounter physical and technical challenges. Obstruction of physical abilities that are require for the specific tasks and the limits of supplies that are necessary for job accomplishment (Al-Minqash, 2007). On the other hand, organizational challenges appear with unfavourable organizational structure that hinder women's performance of administrative duties as well as leadership roles (Abu-Khader, 2012; Al-Minqash, 2007). In this vein, under-empowerment inhibits women in taking decision, eliciting change and performing administrative roles (Abu-Khader, 2012; Al-Kubaisi, 2004). Sometimes, they face demeaning and unwelcoming behaviour from the colleagues and subordinates (Abu-Khader, 2012). 1) individual factors, such as feelings of a lack of self-worth; 2) family factors, such as childcare responsibilities; 3) organizational factors, such as unequal promotion criteria for women and men; and 4) cultural factors, such as social norms and traditions (Bombuwela \& Alwis, 2013). The above discussion, it can be summarized that women generally face four types of general challenges, such as 1) socio-cultural, 2) organizational, 3) economic and 4) individual. Recently (Khattab \& Rosette, 2017) categorised eight types barriers that women face in the workplace. Those are 1) gender-based stereotypes, 2) work-life conflict, 3) 
self-imposed constraints, 4) social network limitations, 5) biased organizational policies, 6) non-gender based discrimination, 7) inadequate qualification and 8) minimal existing representation. Based on the published literary works on higher education of Saudi, the following sections of this paper are presenting the challenges and barriers that women leaders used to encounter.

\subsection{Four General Challenges}

\subsubsection{Individual/ Personal Challenges}

Saudi women are majorly facing four general challenges that are elaborately discussed below.

Individual or self-challenges refer to women's personal characteristics that disfavor them in practicing leadership roles (Al-Shihabi, 2008). It also indicates the physical ability that limit women to execute their duties (Al-Jaradat, 2014; Al-Minqash, 2007). Lack of confidence is also another personal issue that holds back women in pursuing leadership. Sometimes, they exhibit physiological, psychological and intellectual incapacity to play their duties (Almaki, Silong, Idris, \& Wahat, 2016). In the same vein, their lack of ability to implement positional power, executing strategic leadership technique, adapting with the change and working hour push them backward (Al-Jaradat, 2014). On the other hand, Saudi women are considered highly emotional and family bounded (Al-kayed, 2015). Women, particularly is the traditional societies are obliged to carry family responsibilities, such as raising children, taking care of husband and other family members while doing the household chores. Those obligations seem to be barriers in their career development as well as academic progress (Hodges \& Hodges, 2017; Neale \& Özkanli, 2010). Leadership position means a lot of responsibilities. In order to accomplish those duties, women need to have proper skills, experience, abilities to balance over family and job as well as to the change in job environment and unfavorable organizational structure. Failing to do so, women encounter conflict as well as failure in their administrative job (Almaki et al., 2016).

\subsubsection{Socio-cultural Challenges}

Socio cultural challenges include the prevailing socio-cultural issues, traditional influences and family norms. Long standing tribal cultural practice, beliefs and norms hold back Saudi women from the position of organizational leadership (Abu-Khader, 2012). Women are facing high level of discrimination and male dominance that are seemingly rooted in to the traditional socio-cultural condition of this Kingdom (Hamdan, 2005). There is a significant connection of religion and culture on women employment. Conservative culture and strict religious practices hold back women from doing job (Alselaimi, 2012). Due to traditional beliefs they are sometimes neglected collaborating with their male subordinates, colleagues and counterparts (Al-Jaradat, 2014). Besides, men's narrow views towards women's abilities and antipathy in hiring them deprive women of gaining superior administrative position (Billing, 2011). Saudi men carry the idea of Qiwama (Guardianship). They consider themselves the guardians or controller of women. Thus, it is difficult to deal with the men who consider themselves superior to women (Abalkhail, 2017) Besides, lack of freedom is another important issue. Women need permission from their guardians prior to make any 
decision. This obligation denounces their progress as well as discourage to become administrator (Almaki et al., 2016; Almenkash, Abdulaziz, Shaman, Haijan, \& Dagsh, 2007). Another typical barriers for women in ascending the higher management position is stereotype gender approach of the society (Özkanli \& White, 2008). Culturally men perceive women less effective and sometimes unsuitable for the administrative position. But, men are believed more efficient in decision making. Assumingly, the reason behind of this notion is the patriarchal social structure and long prevailed presence of man in the leadership position. Saudi people deeply values the family and tradition. Men are expected to be career oriented as well as bread winners. On the other hand, women are family oriented (Alselaimi, 2012). So, if women look for financial freedom, most of the time they are discouraged by the male family members. This society tends to decline any developmental approach if it is threatening to the traditional family unit (AlMunajjed, 2010). Conservative groups in Saudi expressed worries about female participation in job being worried about the impairment of the existing religious norm and social culture. This group of people believe that women employment may negatively affect Saudi's culture (Alselaimi, 2012).

\subsubsection{Economic Challenges}

The government of Saudi has realized that women empowerment can positively contribute to the national economy. Their potentials which is not less than Saudi men can enhance social development if they are encouraged to be functioning in the public sphere (Shapira, Arar, \& Azaiza, 2010). Therefore, Saudi government extended women participation in the public domain. Government also signed the UN declaration against 'discrimination against women' (Vidyasagar \& Rea, 2004). Besides, the Saudization policy supports and encourage women engagement with the national economy. This policy widened women's participation in the job market (AlMunajjed, 2010). But, wage, age and education, part-time job opportunities are the important contributing factors in job participation by the women (Alselaimi, 2012). These issues are not properly addressed in Saudi Arabia. Therefore, it is difficult for Saudi women to balance the work and family life. Though, there is an economic reformation but women in this kingdom are still facing challenges.

\subsubsection{Organizational Challenges}

Organizational and administrative challenges intercept women in taking superior position (Still, 2006). Saudi women face some negative issues in the organizational environment that hinder their academic leadership roles as well as slows down the institutional achievement (Abu-Khader, 2012; Al-Minqash, 2007). The existence of inequity in the organizational environment, inadequate financial allocations, lack of training and education are also important factors that affect women leadership in Saudi (Al Qahtani, 2006; Tomàs, Lavie, del Mar Duran, \& Guillamon, 2010). Disfavoring and uncooperative behaviors of the subordinates, long working hours and lack of authoritative power are legging them behind (Al-kayed, 2015; Bilen-Green, Froelich, \& Jacobson, 2008). Several other factors are linked with the organizational challenges, those are managing different personalities, workload and administrative tasks etc. (Al Qahtani, 2006; Still, 2006). The workloads sometime go beyond women's capabilities if their responsibilities are not properly allocated considering their 


\section{Macrothink}

International Journal of Learning and Development

ISSN 2164-4063

2018, Vol. 8, No. 2

family obligation (Almaki et al., 2016). Hence, time constraint, job-demands and forces for promotion may separate women from their families. Saudi women leaders face organizational challenges while dealing with different personalities, over workload and internal conflict. Lack of acceptance in the organizational domain women as leader is one of the most debating issues. Furthermore, due to lack of experience they meet some kind of hardship of coping with the situation. Thus, they find difficulties pursuing their duties in the changing environment (Almaki et al., 2016). It can be concluded that the organizational environment is Saudi is not entirely women friendly.

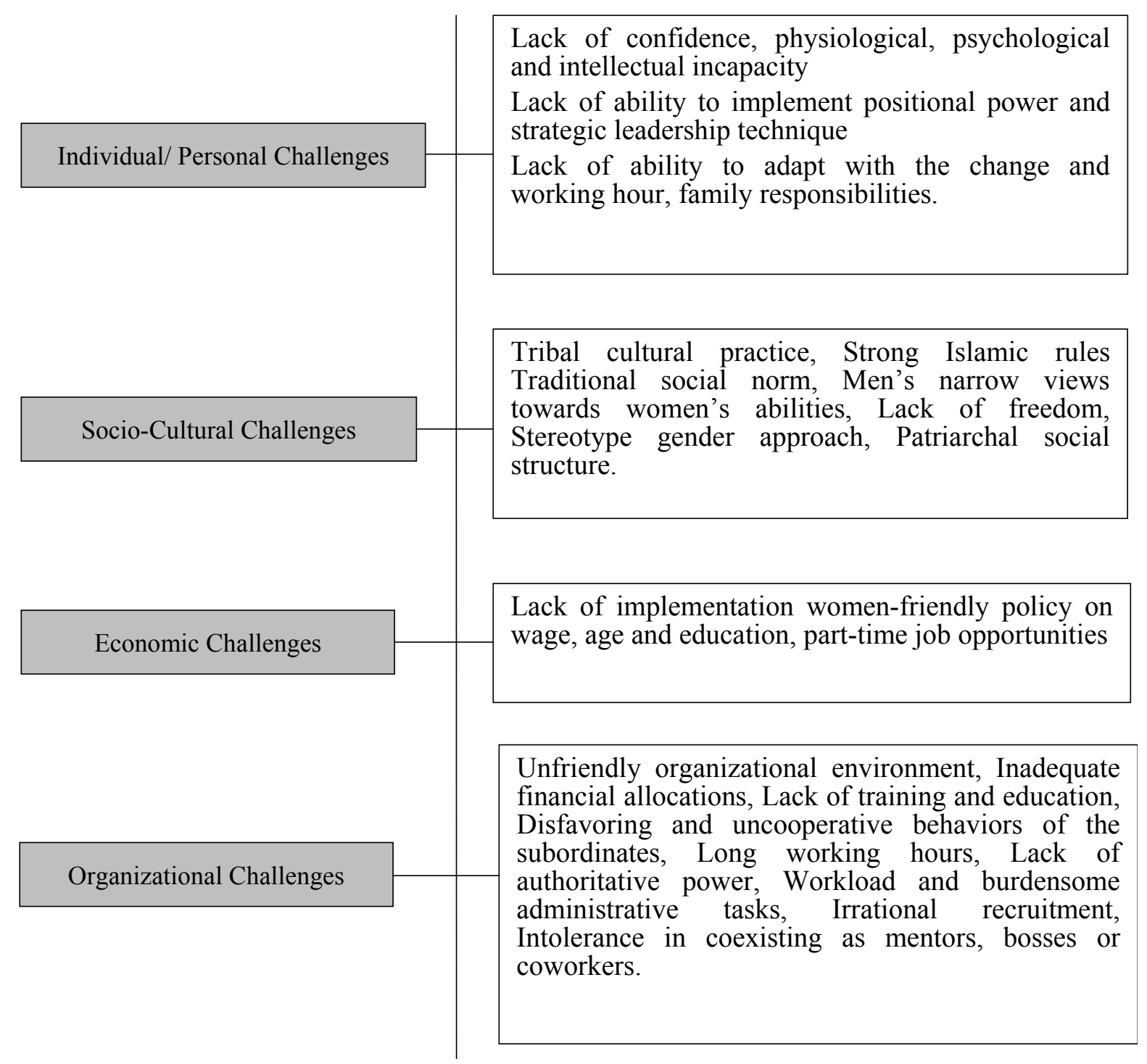

Figure 1. Challenges that Saudi Women are Facing 


\section{$\Lambda$ Macrothink}

\subsection{Workplace Barriers}

\subsubsection{Gender-Based Stereotype}

The term 'gender-based stereotypes' considers women are to be relationship oriented, kind, worm, nurturing and helpful. This perspective doesn't regard women having skills and abilities for pursuing leadership roles (Khattab \& Rosette, 2017). In many instance leadership is stereotyped as a masculine domain (Hamdan, Alexander, \& Al-Hattami, 2016). However, there is a research supported notion that males are more competent than females in work (Burns \& Martin, 2010). Men's negative perception towards women 'representation' and 'surveillance' make women's work environment unfriendly (Kemp, Angell, \& McLoughlin, 2015). In Saudi context, this myopic notion seems contravening in the workplace and depriving women of reaching the superior position even if they deserve. In this country stereotypes gender-roles, negative views towards women's leadership, lack of freedom are the common obstacles for women's progress (Almaki et al., 2016). The patriarchal masculine aspects, authoritative approach of the management, bureaucratic organizational structure (Abdallah M Elamin \& Tlaiss, 2015) unequal distribution of power and authority is associated with the Islamic beliefs and tribal traditions (Abdallah M. Elamin, 2012). As a result, women empowerment is backlashed as well as suppressed (Miznah O. Alomair, 2015). According to (Almaki et al., 2016) social attitudes like, stereotypical gender roles, negative view towards women and lack of freedom discourage and inhibit women to play their roles as leaders in the higher education.

\subsubsection{Work-life Conflict}

Work-life conflict occurs when family responsibilities contend with work responsibilities. Sometimes, women ignore promotions in order to avoid interference with their duties to family (Khattab \& Rosette, 2017). Saudi women's challenges start from their personal lives since their basic duties are managing home and child raising (Danish \& Smith, 2012; Rajeh et al., 2017). They find difficulties to get into job for family orientation as well as religious surveillance (Almansour \& Kempner, 2016). Resistance comes from the family members when they dislike to see women working in the public sphere (Abalkhail \& Allan, 2015). Saudi women face conflict due to family and religious observation. They have to meet the family and social obligation. After accomplishing all the family responsibility they can pursue their job (Almansour \& Kempner, 2016).

\subsubsection{Self-Imposed Constraints}

Self-imposed constraints refer to women's intension not to be career oriented. Thus, they become less focus to their career and tend to give high priority to their family (Khattab \& Rosette, 2017). Family income, marital status and number of children exert significant negative impacts on the probability of joining labour force of the Saudi women (Al - Orabi, 1999).

\subsubsection{Social Network Limitations}

Women may get low access to the social network than men. This constraint negatively impact 
on their career advancement (Khattab \& Rosette, 2017). Saudi women in their professional life are mostly excluded from formal and informal network and deprived of the benefits of corporation based developmental assignment etc. (Omair, 2008).

\subsubsection{Biased Organizational Policies}

Bias organizational policy means the absence of proper facilities, parental leave, flexible working hour and biased performance review. Besides, the presence of masculine norms and absence of female inclusive policies are the obstacles for women to ascend to the leadership position (Khattab \& Rosette, 2017). Many organizations seek for masculine characters with success and achievement including assertiveness, aggressiveness and task-oriented leadership abilities and disfavor recruiting women (Abalkhail, 2017; Elmuti, Jia, \& Davis, 2009; Jogulu \& Wood, 2006). Saudi women reportedly meet bureaucratic infrastructure in the work place (Almansour \& Kempner, 2016). Evidence from Princess Nourah University suggests that female educators experience problems in performing leadership roles in the public spheres. They met bureaucratic research infrastructure in the work place (Almansour \& Kempner, 2016). Besides, lack of coordination between the governmental departments, proper law for women's right protection and lack of policies and unfavorable socio-culture are the common resisting elements (Sadi \& Al-Ghazali, 2010). Besides, centralization of decision making power, lack of authority also resist women pursuing their tasks (Al-Ahmadi, 2011). Reportedly, Saudi women face discrimination in getting promotion, professional training, and development (Abalkhail, 2017).

\subsubsection{Non-Gender Based Discrimination}

Women don't comprise a monolithic category. Some social and demographic categories may create berries along their career path (Khattab \& Rosette, 2017). Some tribal rules, traditional social norm and conservative Islamic ideology resist women to be in the higher management position in Saudi (Neale \& Özkanli, 2010). Alike other sector this problem also appears in the higher education. Family income, marital status and number of children exert significant negative impacts on the probability of joining labour force of the Saudi women. Married women are less likely to participate in the labour force. Saudi people deeply values their family and tradition. They seem ready decline any developmental approach if it is threatening to the traditional family unit (AlMunajjed, 2010).

\subsubsection{Inadequate Qualification}

From Saudi perspective communication skills, specifically linguistic styles are sometimes considered as barriers for joining the hierarchical position. Because, linguistic style is considered as the ability to negotiate with the authority. Another issue is the status quo; where male tends to find themselves at the top always (Oakley, 2000). Two other challenges that negatively affect women's to conduct their leadership roles are taking the right decision and eliciting change (Abu-Khader, 2012; Al-Kubaisi, 2004). Saudi women also face challenges in term of lacking experience. Since, very recently they are engaging with the higher management in education, they may possess less expertise in administrative works and decision making (Özkanli \& White, 2008). Furthermore, lack of capacity and capability and 


\section{Macrothink

managerial efficiency hinder their leadership performance (Al-Ahmadi, 2011). Therefore, they are less likely to be efficient for administrative position in academia (Al-kayed, 2015).

\subsubsection{Minimal Existing Representation}

Saudi women meet constraints in the socio-cultural environment (Jamali, Sidani, \& Safieddine, 2005). Due to the cultural norms, the most likely face exclusion and lack of empowerment (Thompson, 2015). It is noteworthy, the attitude of Saudi males specifically, who are aged or less educated are very traditional and conservative towards working women (Abdallah M. Elamin \& Omair, 2010). Women are underestimated by their subordinates and colleagues (Abu-Khader, 2012). There is a misbelief that women only can hold and sustain leadership position when they embodies male characteristics (Tomàs et al., 2010). Because of this misconception, Saudi women are mostly under-represented. 


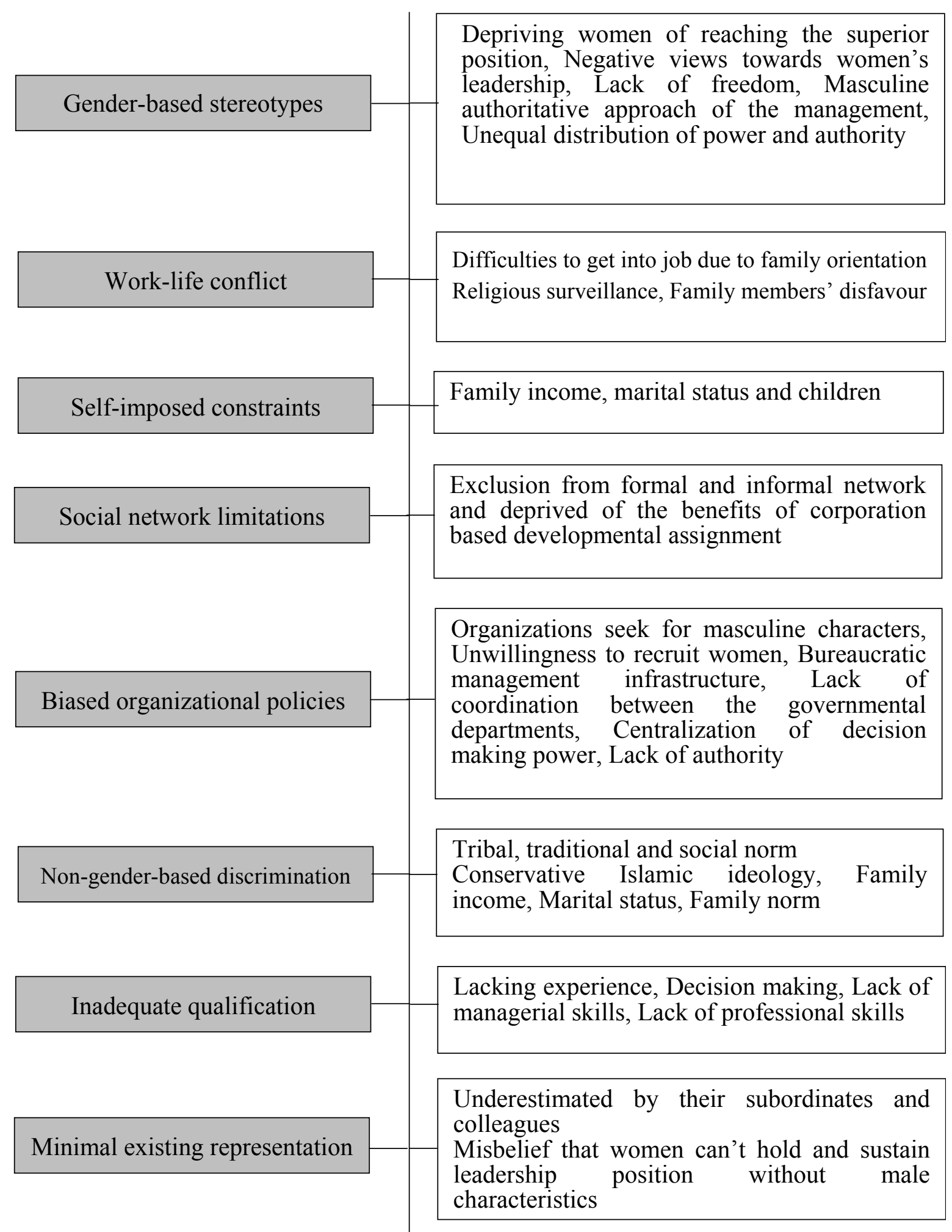

Figure 2. Barriers that Saudi Women are Facing

\subsection{The End-State of Barriers or Challenges are Conflicts}

The recent socio-economic reformation allows Saudi women partaking in the management position as well as playing the leadership roles. But, once they confront the abovementioned 
challenges, workplace sensitivity arises. As a result, they get engaged with assorted conflicts with their male counterparts. Besides, in the male prioritized environment, once women ascend to men's position, conflict occurs (Al - Lamky, 2007; Omair, 2009). Women's promotion to leadership position is ultimately a replacement of long hauled men's inheritance in the Saudi society. This kind of alteration presumably strikes on the patriarchal structure and creates intolerance that gives birth leadership conflicts. On the other hand, leadership position brings a lot of responsibilities to the leaders. In order to accomplish administrative duties, women need to have proper skills, experience, abilities to balance family and job as well as the changing in job environment and unfavorable organizational structure. Women encounter conflict while failing to accomplish their administrative duties (Almaki et al., 2016). Saudi cultural as well as religious norms tend to see man as the household head and bread earner (Abalkhail, 2017). In this case, if women outperform men in term of income generation, conflicts appear due to unacceptance and intolerance by the family (Al - Lamky, 2007; Omair, 2009). Furthermore, women leaders have to maintain different lifestyles in the organizational arena which could be different than their family norms. Hence, changing lifestyle may create contradiction too (Hughes et al., 2009).

\section{Concluding Remarks}

Islam, as a religion doesn't resists women working in the public sphere (Alselaimi, 2012). In spite of being an Islamic country, the women in Saudi Arabia are low probability to participate in higher management in all sectors. Since, they are being more educated recently, they are eager to the procession of the main stream economic activities. But, they are underrepresented due to numerous socio-cultural, political and economic issues. Difficulties in balancing family responsibilities, gender stereotypes, gender roles in the socio-cultural practices, bureaucracy and gender inequality are seemed major obstacles faced by the female leaders.

Saudi Arabia, like other Arab countries has been experiencing the influence of modernization and globalization. Diversity is taking place in the work force and thus, its social culture is becoming heterogeneous. As, gender differences play the vital role in leadership, so, in the organizational context, the roles of male and female leadership need to be balanced. Women should pay attention to the sensitivity of the social norms during their practices of leadership roles. Otherwise, conflict could remain as an irresistible issue. Above all, effective policy implication by the regulatory authorities can enhance women leadership with no conflict.

\section{Acknowledgement and Sponsoring information}

No.

\section{References}

Abalkhail, J. M. (2017). Women and leadership: challenges and opportunities in Saudi higher education. Career Development International, 22(2), 165-183. https://doi.org/10.1108/CDI-03-2016-0029

Abalkhail, J. M., \& Allan, B. (2015). Women's career advancement: mentoring and 
networking in Saudi Arabia and the UK. Human Resource Development International, 18(2), 153-168. https://doi.org/10.1080/13678868.2015.1026548

Abu-Khader, S. (2012). Challenges facing the women's academic leaderships in the higher education institutions in Kingdom of Saudi Arabia. Saudi Higher Education Journal, 3(7).

Al-Ahmadi, H. (2011). Challenges facing women leaders in Saudi Arabia. Human Resource Development International, 14(2), 149-166. https://doi.org/10.1080/13678868.2011.558311

Al-Asfour, A., Al-Asfour, A., Tlaiss, H. A., Tlaiss, H. A., Khan, S. A., Khan, S. A., . . . Rajasekar, J. (2017). Saudi women's work challenges and barriers to career advancement. $\begin{array}{llll}\text { Career Development } & \text { International, } & \text { 22(2), }\end{array}$ https://doi.org/10.1108/CDI-11-2016-0200

Al-bakr, F., Bruce, E. R., Davidson, P. M., Schlaffer, E., \& Kropiunigg, U. (2017). Empowered but not Equal: Challenging the Traditional Gender Roles as Seen by University Students in Saudi Arabia. Paper presented at the FIRE: Forum for International Research in Education.

Al-Jaradat, M. K. M. (2014). Challenges Facing Women Academic Leadership in Secondary Schools of Irbid Educational Area. International Education Studies, 7(5). https://doi.org/10.5539/ies.v7n5p147

Al-kayed, L. (2015). Leadership Challenges for Women Managers in Public Universities in Saudi Arabia Global Journal of Human-Social Science: A Arts \& Humanities - Psychology, 15(4), 1-10.

Al-Kubaisi, A. K. (2004). Knowledge management and organizations development. Alexandria: Modern University Office.

Al-Minqash, S. A. (2007). Leadership over the group leadership with the group: A comparative study between the two male and women leadership styles at King Saud University. Education and Psychology Mission Magazine, 28, 34-45.

Al-Shihabi, E. (2008). Methods for activating the administrative Arab woman's role. Paper presented at the Forum of Role of the Arab Woman in the Sustainable Development and the Civil Society Institution, Doha-Qatar.

Al - Lamky, A. (2007). Feminizing leadership in Arab societies: the perspectives of Omani female leaders. Women in Management Review, 22(1), 49-67. https://doi.org/10.1108/09649420710726229

Al - Orabi, H. M. (1999). Attitudes of Saudi Women towards Participating in the Labour Force. Humanomics, 15(4), 123-140. https://doi.org/10.1108/eb018842

Al Qahtani, M. A. (2006). The effective factors of administrative female leadership innovative management behavior astudy on highereducation organization in Makah's district (Master Thesis), King Abdul-Aziz University, Jeddah.

Almaki, S.-H., Silong, A.-D., Idris, K., \& Wahat, N.-W. A. (2016). Challenges Faced Muslim 
Women Leaders in Higher Education. Journal of Educational and Social Research, 6(3), 75-86. https://doi.org/10.5901/jesr.2016.v6n3p75

Almansour, S., \& Kempner, K. (2016). The role of Arab women faculty in the public sphere. Studies in Higher Education, 874-886. https://doi.org/10.1080/03075079.2016.1147723

Almenkash, S., Abdulaziz, M., Shaman, A., Haijan, A., \& Dagsh, N. (2007). The issue of management women/men in higher education institutions for girls, the draft plan for the future of higher education in the kingdom of Saudi Arabia. Al-Riyadh: King Abdullah Institute for Research Consultancy Studies.

Almunajjed, M. (1997). Women in Saudi Arabia Today. Palgrave Macmillan UK.

AlMunajjed, M. (2010). Women's Employment in Saudi Arabia A Major Challenge. Dubai: Booz \& Company.

Alotaibi, F., Cutting, R., \& Morgan, J. (2017). A Critical Analysis of the Literature in Women's Leadership in Saudi Arabia. International Journal of Business Administration and Management Research 3(1), 29-36. https://doi.org/10.24178/ijbamr.2017.3.1.29

Alselaimi, R. (2012). Female participation in the Saudi Workforce: A Saudi perspective of key barriers. Curtin Graduate School of Business, Curtin University.

Arar, K., \& Oplatka, I. (2016). Current Research on Arab Female Educational Leaders' Career And Leadership. In A. J. Bowers, A. R. Shoho, \& B. G. Barnett (Eds.), Challenges and Opportunities of Educational Leadership Research and Practice (pp. 87-114): Information Age Publishing

Bilen-Green, C., Froelich, K. A., \& Jacobson, S. W. (2008). The Prevalence of Women in Academic Leadership Positions, and Potential Impact on Prevalence of Women in the Professorial Ranks. Paper presented at the WEPAN Conference Proceedings.

Billing, Y. D. (2011). Are Women in Management Victims of the Phantom of the Male Norm? Gender, Work \& Organization, 298-317. https://doi.org/10.1111/j.1468-0432.2010.00546.x

Bombuwela, P., \& Alwis, A. A. (2013). Effects of glass ceiling on women career development in private sector organizations-Case of Sri Lanka. Journal of Competitiveness, 5(2). https://doi.org/10.7441/joc.2013.02.01

Burns, G., \& Martin, B. N. (2010). Examination of the Effectiveness of Male and Female Educational Leaders Who Made Use of the Invitational Leadership Style Of Leadership. Journal of Invitational Theory and Practice, 16, 30-56.

Danish, A. Y., \& Smith, H. L. (2012). Female entrepreneurship in Saudi Arabia: opportunities and challenges. International Journal of Gender and Entrepreneurship, 4(3), 216-235.

https://doi.org/10.1108/17566261211264136 


\section{Macrothink}

International Journal of Learning and Development

ISSN 2164-4063

2018, Vol. 8, No. 2

Elamin, A. M. (2012). Perceived organizational justice and work-related attitudes: a study of Saudi employees. World Journal of Entrepreneurship, Management and Sustainable Development, 8(1), 71-88. https://doi.org/10.1108/20425961211221633

Elamin, A. M., \& Omair, K. (2010). Males' attitudes towards working females in Saudi Arabia. Personnel Review, 39(6), 746-766. https://doi.org/10.1108/00483481011075594

Elamin, A. M., \& Tlaiss, H. A. (2015). Exploring the relationship between organizational citizenship behavior and organizational justice in the Islamic Saudi Arabian context. Employee Relations, 37(1), 2-29. https://doi.org/10.1108/ER-03-2014-0033

Elmuti, D., Jia, H., \& Davis, H. H. (2009). Challenges Women Face in Leadership Positions and Organizational Effectiveness. An Investigation Journal of Leadership Education, 8(2), 167-186. https://doi.org/10.12806/V8/I2/RF4

Europian-Parliament. (2004). Notes on Human Rights in Saudi Arabia. Retrieved from DG External Policies of the Union, Directorate B: Faisal, M. R. (2012). Education and Women Empowerment in Saudi Arabia. Quarterly Journal of Chinese Studies, 4(3), 96-110.

Hamdan, A. (2005). Women and education in Saudi Arabia: Challenges and achievements. International Education Journal, 6(1), 42-64.

Hamdan, A., Alexander, N., \& Al-Hattami, A. (2016). Saudi Female Students' Perceptions of Leadership: An Overview. Advancing Women in Leadership, 36, 36-48.

Havril, A. K. (2015). Improving Intercultural Competence of Female University Students in EFL within Saudi Arabia. Procedia - Social and Behavioral Sciences, 192, 554-566. https://doi.org/10.1016/j.sbspro.2015.06.091

Hodges, J., \& Hodges, J. (2017). Cracking the walls of leadership: women in Saudi Arabia. Gender in Management: An International Journal, 32(1), 34-46. https://doi.org/10.1108/GM-11-2015-0106

Hughes, R. L., Ginnett, R. C., \& Curphy, G. J. (2009). Leadership enhancing the lessons of experience. New York: McGraw-Hill.

Human-Rights-Watch. (2004). Saudi Arabia. Retrieved from http://pantheon.hrw.org/legacy/english/docs/2006/01/18/saudia12230.htm

Jamali, D., Sidani, Y., \& Safieddine, A. (2005). Constraints facing working women in Lebanon: an insider view. Women in Management Review, 20(8), 581-594. https://doi.org/10.1108/09649420510635213

Jogulu, U., \& Wood, G. (2006). The role of leadership theory in raising the profile of women in management. Equal Opportunities International, 25(4), 236-250. https://doi.org/10.1108/02610150610706230

Kemp, L. J., Angell, L., \& McLoughlin, L. (2015). The symbolic meaning of artifacts for the workplace identity of women in academia. Gender in Management: An International Journal, 30(5), 379-396. https://doi.org/10.1108/GM-07-2013-0080 
Khattab, J., \& Rosette, A. S. (2017). Workplace barriers faced by women leaders in emerging markets. Women Leadership in Emerging Markets: Featuring 46 Women Leaders, 164.

Le Renard, A. (2008). "Only for Women:" Women, the State, and Reform in Saudi Arabia. The Middle East Journal, 62 (4), 1-21. https://doi.org/10.3751.62.4.13

Ministry of Education (in cooperation with the Ministry of Higher Education and the Technical and Vocational Training Corporation). Planning and Development, General Directorate of Research, Kingdom of Saudi Arabia (2004). National Report on Education Development In the Kingdom of Saudi Arabia. www.ibe.unesco.org/International/ICE47/English/Natreps/reports/sarabia_ar.pdf

Ministry of Education, Kingdom of Saudi Arabia (2015). Ministry of Education Establishment. $\quad$ Retrieved April 1, 2018, from https://www.moe.gov.sa/en/TheMinistry/Education/Pages/EstablishmentoftheMinistryofEduc ation.aspx

Ministry of Higher Education, Kingdom of Saudi Arabia. (2013). The Current Status of Higher Education in The Kingdom of Saudi Arabia. Retrieved December 31, 2016, from https://www.moe.gov.sa/ar/Ministry/Deputy-Ministry-for-Planning-and-Information-affairs/T he-General-Administration-of-Planning/Documents/333.pdf

Miznah O. Alomair. (2015). Female Leadership Capacity and Effectiveness: A Critical Analysis of the Literature on Higher Education in Saudi Arabia. International Journal of Higher Education, 4(4). https://doi.org/10.5430/ijhe.v4n4p81

Neale, J., \& Özkanli, O. (2010). Organisational barriers for women in senior management: A comparison of Turkish and New Zealand universities. Gender and Education, 22(5), 547-563. https://doi.org/10.1080/09540250903524113

Neva, H. A., Hala, G., \& Gregory, P. (2014). Gender Differences of Perceived Leadership Skills Among Saudi Students. Advancing Women in Leadership, 34, 11-18.

Nisreen, A. B., \& Nadia, Y. (2011). Impact of the Demand of Women Higher Education: A New Dimension Case: Saudi Arabia. GSTF Business Review (GBR), 1(2), 161-166. https://doi.org/10.5176/978-981-08-8957-9_QQE-031

Oakley, J. G. (2000). Gender-based Barriers to Senior Managenient Positions: Understanding the Scarcity of Female CEOs. Journal of Business Ethics, 27(321-334).

Omair, K. (2008). Women in management in the Arab context. Education, Business and Society: Contemporary Middle Eastern Issues, 1(2), 107-123. https://doi.org/10.1108/17537980810890293

Omair, K. (2009). Arab women managers and identity formation through clothing. Gender in Management: An International Journal, 24(6), 412-431. https://doi.org/10.1108/17542410910980397

Oplatka, I., \& Herts-Lazarovits, R. (Eds.). (2006). Women Principals in a Multicultural 
Society: New Insights Into Feminist Educational Leadership. Sense Publishers.

Özkanli, Ö., \& White, K. (2008). (2008). Leadership and strategic choices: Female professors in Australia and Turkey. Journal of Higher Education Policy and Management, 30(1), 53-63. https://doi.org/10.1080/13600800701745051

Rajeh, M., Nicolau, B., Pluye, P., Qutob, A., \& Esfandiari, S. (2017). Are There Barriers for Professional Development of Women Dentists? A Qualitative Study in Saudi Arabia. JDR Clinical \& Translational Research, 2(2), 119-131. https://doi.org/10.1177/2380084416685083

Sadi, M. A., \& Al-Ghazali, B. M. (2010). Doing business with impudence: A focus on women entrepreneurship in Saudi Arabia. African Journal of Business Management, 4(1), 1.

Salkind, N. (2010). Literature Review Encyclopedia of Research Design. Thousand Oaks, California. https://doi.org/10.4135/9781412961288

Shapira, T., Arar, K., \& Azaiza, F. (2010). Arab women principals' empowerment and leadership in Israel. Journal of Educational Administration, 48(6), 704-715. https://doi.org/10.1108/09578231011079566

Still, L. V. (2006). Where are the women in leadership in Australia? Women in Management Review, 21(3), 180-194. https://doi.org/10.1108/09649420610657371

Thompson, M. C. (2015). Saudi Women Leaders: Challenges and Opportunities. Journal of Arabian Studies, 5(1), 15-36. https://doi.org/10.1080/21534764.2015.1050880

Tomàs, M., Lavie, J. M., del Mar Duran, M., \& Guillamon, C. (2010). Women in academic administration at the university. Educational Management Administration \& Leadership, 38(4), 487-498. https://doi.org/10.1177/1741143210368266

UNDP. (2013). Expenditure on Education, Public (\% of GDP) (\%). Retrieved from http://hdr.undp.org/en/content/expenditure-education-public-gdp

$\begin{array}{llll}\text { UNICEF. } & \text { (2013). Saudi Arabia. } & \text { Retrieved }\end{array}$ http://www.unicef.org/infobycountry/saudiarabia_statistics.html

Vidyasagar, G., \& Rea, D. M. (2004). Saudi women doctors: gender and careers within Wahhabic Islam and a 'westernised' work culture. Women's Studies International Forum, 27(3), 261-280. https://doi.org/10.1016/j.wsif.2004.06.008

\section{Copyright Disclaimer}

Copyright for this article is retained by the author(s), with first publication rights granted to the journal.

This is an open-access article distributed under the terms and conditions of the Creative Commons Attribution license (http://creativecommons.org/licenses/by/4.0/). 